\title{
Timing and processes of Himalayan and Tibetan uplift
}

\author{
T Mark Harrison†* and An Yin $\ddagger$ \\ † Research School of Earth Sciences, The Australian National University, Canberra, A.C.T. 0200, AUSTRALIA \\ ¥ Department of Earth and Space Sciences and IGPP, UCLA, Los Angeles, CA 90095 USA
}

*To whom correspondence should be addressed.E-mail:Director.RSES@anu.edu.au

Numerical simulations indicate that major climate change can be triggered by the appearance of a mountain belt or the uplift of a large region. There is accumulating evidence that the appearance of a high and extensive Himalayan-Tibetan mountain system significantly influenced Neogene climate (Hahn and Manabe 1975). Although long appreciated as the best modern example of a continental collision orogen, our knowledge of the uplift history of the Indo-Asian collision is only now coming into focus due in part to the still relatively blunt instruments we have at our disposal for determining elevation histories.

Models advanced to explain the evolution of the present distribution of crust within the Indo-Asian orogen include those that predict wholesale uplift (mantle delamination, delayed under-plating), progressive growth (Indian under-thrusting, Asian under-thrusting, continental injection), lateral responses (orogenic collapse, horizontal extrusion), and inheritance of an elevated terrane (multiple collision, intra-arc thickening). Investigations of the timing and magnitude of deformation in Tibet and surrounding regions provide some constraints on the crustal thickening and elevation histories that help select among these models. However, the pattern of crustal displacements in response to the collision is inconsistent with most permutations of these single mechanisms but instead requires a specific, timedependent transfer among several of these processes, often with multiple mechanisms operating simultaneously. The parameters that appear most important in dictating which mechanisms are dominant at any one time are: the location and geometry of preexisting lithospheric weakness, the distribution of topography before and during the collision, the geometry of the indenter and extruded blocks, the magnitude of boundary stresses, and the age of the lithosphere (Kong et al. 1997).

The Tibetan Plateau began to form locally in response to the collision of the Lhasa block with southern Asia during the Early Cretaceous, particularly in central and southern Tibet. For example, this event is well-documented in the northern Lhasa block where a fold and thrust belt developed between 144-110 $\mathrm{Ma}$ and remained substantially elevated until the onset of the collision of India with Asia. The $>1400 \mathrm{~km}$ of N-S shortening absorbed by the Himalayan-Tibetan orogen since the onset of collision at $\sim 70 \mathrm{Ma}$ is manifested in two ways: 1 ) discrete thrust belts with relatively narrow zones of contraction or regional decollement (e.g., MCT, Qimen Tagh-North Kunlun thrust system), and 2) distributed shortening over a wide region involving basement rocks (e.g., Nan Shan and western Kunlun thrust belts). This crustal shortening began synchronously in the early Paleogene in the Tethyan and Eo-Himalaya and in the Nan Shan, some $1400 \mathrm{~km}$ to the north suggesting that the plateau began to be constructed between the northern margin of India and the Qilian suture zone simultaneously, and not through sequential propagation from south to north. Paleozoic and Mesozoic tectonic histories have exerted strong control on the Cenozoic strain distribution and history during development of the plateau (e.g., Cenozoic thrust belts developed along pre- existing sutures; the Triassic flysch complex is spatially correlated with Cenozoic volcanism and thrusting; basement-involved thrusts in the Nan Shan and Kunlun Shan follow pre-Cenozoic tectonic belts.

Evidence in the form of deformation and clastic sediment production indicates that the Nan Shan and Fenghuo Shan regions of northern Tibet were actively uplifting at about 45-32 Ma. Possibly in response to this thickening, the left-lateral Red River fault initiated at ca. 35 Ma permitting the eastward extrusion of Indochina until $\sim 17 \mathrm{Ma}$. This had the effect of reducing the rate of crustal thickening in Tibet, perhaps by accommodating as much as one-half of Indo-Asian convergence during the Oligocene (37-24 Ma). Thin-skinned thrusting was occurring in the Tethyan Himalaya throughout the Paleogene while cover rocks on the northern margin of the Indian shield experienced significant crustal thickening. Although little crustal thickening of Tibet within fold and thrust belts can be documented for the Eo-oligocene (58-24 Ma), mass balance considerations all but require that channeled flow in the ductile lower crust (e.g., Zhao and Morgan 1985) has continuously thickened the crust, uniformly raising much of Tibet to between 1 and $3 \mathrm{~km}$ in elevation.

Thus by the beginning of the Late Oligocene, a relatively low Tibetan Plateau (except, perhaps, along the collision zone between the Lhasa and Qiangtang blocks) was likely in existence while the Tethyan Himalaya was topographically subdued and the proto-Himalayan range was shedding little sediment. At ca. $28 \mathrm{Ma}$, crustal thickening began in southern Tibet along the Gangdese Thrust, moving southward to the Himalaya shortly thereafter in a series of south-directed thrusts which appear to be splays of the same decollement. We can infer the magnitude of this surface uplift from estimates of the amount of crustal shortening and denudation. We think it likely that the Main Central Thrust (MCT) decollement is responsible for generating the 24-9 Ma Himalayan leucogranites which suggests an Early Miocene age for the initial phase of MCT fault activity. This general pattern of propagation toward the foreland was interrupted by the north-directed Renbu Zedong Thrust which was active in southern Tibet between 19-11 Ma. Extension in the High Himalaya along the South Tibetan Detachment System occurred concurrently with slip on the MCT and RZT. The Tien Shan thrusts and thickening in the western Kun Lun were also initiated during the Early Miocene ( 20 Ma). By ca. $20 \mathrm{Ma}$, the Gangdese Shan, Tethyan Himalaya, and High Himalaya were now likely a significant climatic barrier, with an average elevation of perhaps $4-5 \mathrm{~km}$, behind which stood a large but still relatively subdued Tibetan Plateau. At this point, thickening deformation jumped the Tarim basin to the Tien Shan.

Thickening in northwest Tibet, apparently related to transtension along the Altyn Tagh fault, began during the middle Miocene ( $15 \mathrm{Ma})$. Subsequent to Middle Miocene initiation of the Main Boundary Thrust, a broad zone of deformation beneath the MCT fault was active between 10-4 Ma producing the classic Himalayan inverted metamorphic sequences. Recognizing the 
juxtaposition of hanging wall gneisses partially melted at ca. 22 Ma and young (ca. 11-3 Ma), lower grade footwall rocks across this tectonically telescoped section renders unnecessary appeals for high shear stress during faulting in order to create the leucogranite melts (e.g., England et al. 1992).

By $\sim 9 \mathrm{Ma}$, the Tibetan Plateau had attained an average elevation of approximately $5 \mathrm{~km}$ and began to differentially extend $\mathrm{E}-\mathrm{W}$ in a set of $\mathrm{N}-\mathrm{S}$ trending graben. Although the entire plateau is in extension, these features are particularly welldeveloped in southern Tibet, perhaps because of accretion of India to southern Asia leading to higher extensional strains.

The discrete changes we infer in the manner in which continuous Indo-Asian convergence was accommodated over the past ca. 70 Ma provides a cautionary tale against interpreting episodic phenomena in the geological record in terms of discontinuous processes, particularly in light of the growing appreciation that complex physical systems driven by structureless inputs can exhibit highly intermittent dynamics. Perhaps the clearest lesson emerging from our study of the IndoAsian collision is that the continental lithosphere's complex history and geometry exerts a powerful control on continuous plate convergence being manifested in the geological record as episodic phenomena.

\section{References}

England P, P Le Fort, P Molnar and A Pêcher. 1992. Heat sources for Tertiary metamorphism and anatexis in the Annapurna-Manaslu region, Central Nepal. J Geophys Res 97: 2107-28

Hahn DG and S Manabe. 1975. The role of mountains in the south Asia monsoon circulation. JAtmos Sci 32: 1515-1541

Kong X, A Yin and TM Harrison. 1997. Evaluating the role of pre-existing weakness and topographic distributions in the Indo-Asian collision by use of a thin-shell numerical model. Geology 25: 527-30

Zhao W and WJ Morgan. 1985. Uplift of the Tibetan Plateau. Tectonics 4: 359-69 